Article

\title{
Analysis and Comparison of Nutrition Profiles of Canine Milk with Bovine and Caprine Milk
}

\author{
Mengjie Zhang ${ }^{1}$, Xiaomeng Sun ${ }^{1}$, Jianjun Cheng ${ }^{1}$ and Mingruo Guo ${ }^{1,2, *}$ \\ 1 College of Food Science, Northeast Agricultural University, Harbin 150030, China; \\ 18097867089@163.com (M.Z.); sunxm@neau.edu.cn (X.S.); jjcheng@neau.edu.cn (J.C.) \\ 2 Department of Nutrition and Food Sciences, College of Agriculture and Life Sciences, University of Vermont, \\ Burlington, VT 05405, USA \\ * Correspondence: mguo@uvm.edu; Tel.: +1-802-656-8168; Fax: +1-802-656-0001
}

check for updates

Citation: Zhang, M.; Sun, X.; Cheng, J.; Guo, M. Analysis and Comparison of Nutrition Profiles of Canine Milk with Bovine and Caprine Milk. Foods 2022, 11, 472. https://doi.org/

$10.3390 /$ foods 11030472

Academic Editor: Ana M VivarQuintana

Received: 20 December 2021

Accepted: 3 February 2022

Published: 5 February 2022

Publisher's Note: MDPI stays neutral with regard to jurisdictional claims in published maps and institutional affiliations.

Copyright: (C) 2022 by the authors. Licensee MDPI, Basel, Switzerland. This article is an open access article distributed under the terms and conditions of the Creative Commons Attribution (CC BY) license (https:// creativecommons.org/licenses/by/ $4.0 /$ )
Abstract: Pet foods are gaining ground in China. Canine milk substitute formulations are based on their milk chemistry. This study aimed to analyze and compare the differences in proteins, fatty acids, minerals, and basic chemical composition between canine, bovine, and caprine milk. Canine milk contains higher contents of protein $(6.62-17.34 \%)$, fat $(8.92-14.31 \%)$, and ash $(1.11-1.81 \%)$, and a lower content of lactose (1.56-3.92\%) compared to bovine and caprine milk. The protein profiles of canine, bovine, and caprine milk were similar as confirmed by sodium dodecyl sulphate-polyacrylamide electrophoresis gel (SDS-PAGE). The quantification of proteins in canine, bovine, and caprine milk were significantly different when analyzed by inverse high-performance liquid chromatography. Canine milk showed higher contents of monounsaturated fatty acids (29.71-32.95\% of total fatty acids) and polyunsaturated fatty acids (16.83-20.56\% of total fatty acids), but a lower proportion of saturated fatty acids (47.57-53.18\% of total fatty acids) than bovine and caprine milk. The essential fatty acids ARA and DHA were also found in canine milk in the ranges of $0.82-1.77 \%$ and $0.12-0.43 \%$ of total fatty acids, respectively. Canine milk had higher levels of $\mathrm{Mg}, \mathrm{K}, \mathrm{Na}, \mathrm{Fe}$, and $\mathrm{Zn}$ than those in bovine and caprine milk. The nutrient profile of canine milk was different from that of bovine and caprine milk. There were differences in nutritional compositions of the milk samples from four breeds, and Rottweiler milk had the highest nutritional content. The data of this study may provide useful information about the nutritional needs of puppies during their first months of life and the basic information for formulations of puppy milk substitutes.

Keywords: canine milk; chemical composition; protein; fatty acids; mineral

\section{Introduction}

Increasing numbers of families raise dogs as partners and care for their health and growth. Breast milk is an essential source of nutrients (proteins, lipids, carbohydrates, vitamins, and minerals) for newborn puppies [1,2]. The bioactive composition of breast milk can regulate the development of the intestinal tract and immune system via its antimicrobial and anti-inflammatory effects $[3,4]$. When breastfeeding is unavailable, substitution with formula becomes an excellent alternative to meet the nutritional needs of puppies. It was reported that some publicly available milk powder substitutes may be deficient or excessive in certain nutrients, which can affect the development of puppies [5,6]. Therefore, it is necessary to perform systematic and comprehensive analyses of the nutrients and bioactive components in canine milk when developing formulations of puppy milk substitutes.

The nutrient profiles (protein, lipids, and carbohydrate content) of canine milk differ from those of other mammals [7]. Some active components in canine milk, including oligosaccharides ( $3^{\prime}$-sialyllactose, $6^{\prime}$-sialyllactose, and $2^{\prime}$-fucosyllactose), nucleotides (adenosine $5^{\prime}$-monophosphate, cytidine $5^{\prime}$-monophosphate, guanosine $5^{\prime}$-monophosphate, and uridine $5^{\prime}$-monophosphate), and immunoglobulin $\mathrm{G}$ were significantly different from 
other mammals $[2,8,9]$. However, the protein profile, fatty acid composition, and mineral content of canine milk are seldom reported.

Bovine and caprine milk are the main ingredients of the formulations of puppy milk alternatives [10]. Some clinical studies found that bovine colostrum reduced the recurrence rate of gastroenteritis in puppies and improved their fecal quality [11]. Bovine colostrum enhanced the immune response and the diversity and stability of intestinal microbes in dogs [12]. However, puppies have lower lactase activity in the small intestine after weaning, which leads to lactose intolerance [13]. Therefore, bovine and caprine milk cannot be used as a direct substitute for breast milk to meet the nutritional needs of puppies.

The objectives of this study were to analyze the chemical composition, including the protein profile, fatty acids, and minerals of canine milk from four breeds of dogs (Labrador, Caucasian Sheepdog, Golden Retriever, and Rottweiler), as well as bovine and caprine milk using sodium dodecyl sulphate-polyacrylamide gel electrophoresis (SDS-PAGE), reverse phase high-performance liquid chromatography (RP-HPLC), gas chromatography (GC), and inductively coupled plasma mass spectrometry (ICP-MS).

\section{Materials and Methods}

\subsection{Materials}

Standards of $\alpha$-lactalbumin (purity $>85 \%$ ), $\beta$-lactoglobulin (purity $>90 \%$ ), and fatty acids (FAs) (Supelco 37-component FAME mix) were purchased from Sigma-Aldrich. The casein standard (purity $>95 \%$ ) was obtained from the resource platform of the National Standard Material (Beijing, China). An internal standard (methyl salicylate) was purchased from Macklin (Shanghai, China). HPLC-grade acetonitrile, methanol, and n-hexane were purchased from the Fisher Scientific Company (Waltham, MA, USA). HPLC-grade chloroform and trifluoroacetic acid (TFA) were obtained from Aladdin. All other chemicals used were of analytical grade. The water used in this study was filtered through a Millipore Mill-Q water purification system (Millipore Corp., Milford, MA, USA).

\subsection{Collection of Milk Samples}

Bovine (Holstein) and caprine (Saanen) milk samples were purchased from a local farm in Harbin (China). Canine milk samples were collected from four breeds of healthy dogs (20-25 kg, 2-4 weeks of lactation) including Labrador $(n=4)$, Caucasian Sheepdog $(n=1)$, Golden Retriever $(n=1)$, and Rottweiler $(n=1)$. The milk obtained from different dogs was analyzed separately, except for the milk of the Labrador which was mixed for analysis. After manual collection, samples were immediately transferred to PET bottles, kept in an icebox at a temperature of $2-4{ }^{\circ} \mathrm{C}$ during transportation, and stored at $-80{ }^{\circ} \mathrm{C}$ for further analysis.

\subsection{Analysis of Basic Chemical Composition}

All milk samples were thawed at $37^{\circ} \mathrm{C}$ before chemical composition analysis. The protein content was determined using the micro-Kjeldahl method [14], and total proteins were obtained by multiplying the nitrogen percentage by a factor of 6.38 . The fat content was measured according to IDF 105E (2008) [15]. Total solids (TS) were determined by the weight method after drying in a forced-draft oven at $105^{\circ} \mathrm{C}$ until a steady weight was achieved according to IDF 021B (1987) [16]. Ash content was tested after the mineralization of milk at $550{ }^{\circ} \mathrm{C}$ for $4 \mathrm{~h}$ according to GB 5009.4 (2016) [17]. Lactose content was determined by the difference of total solids minus other solid components. All measurements were performed in triplicate.

\subsection{SDS-PAGE Analysis}

Milk samples for SDS-PAGE were prepared according to the method described by Wang et al. [18]. A concentrated gel (5\%) and separated gel (12\%) were prepared for the SDSPAGE analysis. All the milk samples were diluted to $5 \mathrm{mg} / \mathrm{mL}$ using Milli-Q water $(10 \mu \mathrm{L})$ and boiled for 5 min after mixing with $5 \times$ SDS loading buffer CW0028S (Cwbiotechnology, 
Taizhou, China). Electrophoresis was conducted by a Mini-protean Tetra Electrophoresis System (Bio-Rad, Hercules, CA, USA). The gels ran at $85 \mathrm{~V}$ for $0.5 \mathrm{~h}$ in stacking gels and then $120 \mathrm{~V}$ for $1.5 \mathrm{~h}$ in separation gels. Protein staining was performed for $1 \mathrm{~h}$ using the Coomassie brilliant blue fast staining solution (Solarbio Co., Ltd, Beijing, China.). Ultrapure water was used for the decolorization treatment. A protein ladder ranging from 10 to 180 kDa (Biosharp Life Sciences, Hefei, China) was used as the molecular weight standard.

\subsection{Analysis of Reverse Phase High Performance Liquid Chromatography (RP-HPLC)}

Milk samples were skimmed by centrifugation at $10,000 \mathrm{rpm}$ for $30 \mathrm{~min}$ at $4{ }^{\circ} \mathrm{C}$, diluted with a mixed solution containing $8 \mathrm{M}$ urea, $165 \mathrm{mM}$ Tris, $44 \mathrm{mM}$ sodium citrate, and $0.3 \%(v / v) \beta$-mercaptoethanol [19]. Caprine and bovine milk were diluted 5-fold and canine milk was diluted 8-fold. After incubation at $37^{\circ} \mathrm{C}$ for $1 \mathrm{~h}$, samples were filtered through a $0.22-\mu \mathrm{m}$ membrane for liquid chromatographic analysis. The identification and quantification of milk proteins were performed using a bovine milk protein standard containing $\alpha$-lactalbumin (purity $>85 \%$, Sigma), $\beta$-lactoglobulin (purity $>90 \%$, Sigma), and casein (purity $>95 \%$, National Standard Material Resource Platform, Beijing, China). The standards were prepared as 1,2,3,4, and $5 \mathrm{mg} / \mathrm{mL}$ solutions with the above mixed solution.

An RP-HPLC analysis was performed according to the methods of Bobe et al. and Bekhit et al. [20,21] with some modifications using the Shimadzu DGU-20A3R liquid chromatography system (Shimadzu Co., Tokyo, Japan) equipped with an SPD-20A UV detector. Separations were performed on a reversed-phase analytical column C18 (Agilent TC-C18, Agilent Technologies) with $5-\mu \mathrm{m}$ particle size (250 $\mathrm{mm} \times 4.6 \mathrm{~mm}$ I.D.), and the column temperature was maintained at $40{ }^{\circ} \mathrm{C}$. The flow phase A was deionized water containing $0.1 \%$ trifluoroacetic acid (TFA) and the flow phase $\mathrm{B}$ was acetonitrile solution containing $0.1 \%$ trifluoroacetic acid (TFA). The flow rate was $0.8 \mathrm{~mL} / \mathrm{min}$ and the UV detection wavelength was set at $220 \mathrm{~nm}$. The sample injection volume was $10 \mu \mathrm{L}$. The elution gradient conditions of the sample were set as follows: 0-5 min linear gradient from $33 \%$ B to 35\% B; 5-9 min linear gradient from 35\% B to 37\% B; 9-18 min linear gradient from $37 \%$ B to $40 \%$ B; 18-22 min linear gradient from $40 \%$ B to $41 \%$ B; $22-27.5$ isocratic elution $41 \% \mathrm{~B}$; then $27.5-28$ min linear gradient from $41 \%$ B to $43 \%$ B; $28-36$ min linear gradient from $43 \%$ B to $45 \%$ B; 36-40 min linear gradient from $45 \%$ B to $33 \%$ B; followed by isocratic elution for $5 \mathrm{~min}$ at the initial conditions. The peak obtained from the standard solution was analyzed, and the standard curve between the peak area and the elution time was made. The major proteins in the milk samples were quantified and qualitatively analyzed by calculating the area of each peak and peak time of the sample, compared with the reverse HPLC elution map of the standard product.

\subsection{Analysis of Fatty Acids (FAs)}

Fatty acid composition was determined according to the method of Wang et al. [22], with some modifications. One hundred microliters of milk were mixed with $1 \mathrm{~mL}$ of chloroform/methanol $(2: 1, v / v)$ after recovery to room temperature. The mixed solution was ultrasonicated for $30 \mathrm{~min}$ and centrifuged at $10,000 \mathrm{rpm}$ for $15 \mathrm{~min}$ at $4{ }^{\circ} \mathrm{C}$. Two milliliters of sulfuric acid-methanol solution (1\%) were added to the supernatant and methylated in an $80{ }^{\circ} \mathrm{C}$ bath for $30 \mathrm{~min}$. The remaining solvent was blow dried with nitrogen. The dry sample was extracted by adding $1 \mathrm{~mL}$ of $\mathrm{n}$-hexane and washed with $5 \mathrm{~mL}$ deionized water. The samples were prepared by mixing $475 \mu \mathrm{L}$ supernatant with $25 \mu \mathrm{L}$ internal standard (methyl salicylate) for GC analysis.

The fatty acid composition was determined by gas chromatography (Agilent 7890B) equipped with a flame ionization detector (FID) and Chromatography Workstation software. The fatty acid methyl esters (FAMEs) were separated on a capillary column SP-2560 $(100 \mathrm{~m} \times 0.25 \mathrm{~mm}$ ID $\times 0.25 \mu \mathrm{m})$. Hydrogen was used as a carrier gas with the flow of $1 \mathrm{~mL} / \mathrm{min}$, and the temperatures of injector and detector were $250{ }^{\circ} \mathrm{C}$. All samples were injected with $1 \mu \mathrm{L}$, the split ratio was 100:1. The following GC conditions were used: the initial temperature was $140{ }^{\circ} \mathrm{C}$, raised to $180{ }^{\circ} \mathrm{C}$ at a rate of $8{ }^{\circ} \mathrm{C} / \mathrm{min}$, raised to $210{ }^{\circ} \mathrm{C}$ at 
a rate of $8{ }^{\circ} \mathrm{C} / \mathrm{min}$, and then raised to $240{ }^{\circ} \mathrm{C}$ at a rate of $15{ }^{\circ} \mathrm{C} / \mathrm{min}$ and maintained for $4.5 \mathrm{~min}$, finally, raised to $250{ }^{\circ} \mathrm{C}$ at a rate of $5{ }^{\circ} \mathrm{C} / \mathrm{min}$ and maintained for $10 \mathrm{~min}$. The fatty acids in the samples were identified by comparing with the retention time of the standard methyl ester mixture. Fatty acid quantification was calculated by area normalization, and the amount of each fatty acid was expressed as a percentage of the total fatty acids.

\subsection{Analysis of Minerals}

The contents of calcium, magnesium, copper, iron, manganese, sodium, potassium, and zinc in all milk samples were analyzed by the standard method of GB5009.268 (2016) [23]. About $1 \mathrm{~g}$ of milk sample was treated with $5 \mathrm{~mL}$ of $\mathrm{HNO}_{3}$ in a microwave digestion tank, then heated on a microwave digestion apparatus at $120^{\circ} \mathrm{C}$ for $5 \mathrm{~min}, 150{ }^{\circ} \mathrm{C}$ for $10 \mathrm{~min}$, and $190^{\circ} \mathrm{C}$ for $20 \mathrm{~min}$. The solutions were cooled to room temperature and adjusted to a fixed volume to $25 \mathrm{~mL}$ with Milli-Q water. Mineral levels were determined by ICP-MS. Instrument operating parameters were radio frequency power $1500 \mathrm{~W}$, coolant flow $11 \mathrm{~L} / \mathrm{min}$, auxiliary flow $0.40 \mathrm{~L} / \mathrm{min}$, and nebulizer flow $0.8 \mathrm{~L} / \mathrm{min}$. In addition, nickel/platinum cones were used as sampling cones with an integration time of $28 \mathrm{~s}$, which were optimized for acid solutions.

\subsection{Statistical Analysis}

All analyses took three parallel measurements with data represented by the mean \pm standard difference. A single-factor variance analysis was performed using SPSS 20 (IBM, New York, NY, USA) statistical software. Graphs were made using Origin 2021 (Origin Lab Corporation, Northampton, MA, USA).

\section{Results and Discussion}

\subsection{Analysis of the Chemical Composition of Bovine, Caprine, and Canine Milk}

The chemical composition of different milk samples is shown in Table 1. The composition of Rottweiler milk had a higher content than that reported by Park [24], which might be due to the differences in genetic properties, breeding, feeding conditions, the breed's age, and calving number, diet, and lactation. There were significant differences in the nutritional composition of canine, bovine, and caprine milk $(p<0.05)$. Canine milk had twice the dry matter content than bovine and caprine milk due to its higher content of protein, fat, and ash. The average contents of the gross composition were $6.62-7.57 \%$ protein, $2.76-3.92 \%$ lactose, and 8.92-9.94\% fat in Labrador, Caucasian Sheepdog, and Golden Retriever milk, which were in agreement with studies by Heinze et al. [25] and Oftedal et al. [26]. However, the ash concentration of canine milk was lower than that reported by Baines et al. [27]. The protein, fat, and ash content in Rottweiler milk was significantly $(p<0.05)$ higher than that of Labrador, Caucasian Sheepdog, and Golden Retriever milk. The intake of protein and fat has an important role in the growth and development of mammals. High protein levels could provide essential amino acids for the growth of newborns, and some special proteins can also improve immunity and promote the utilization of trace elements [28]. Fat, a major source of energy in breast milk, has high levels in canine milk, and is easily absorbed and utilized by the gut [29]. Lactose is a major carbohydrate in breast milk and provides energy. The lactose content of Golden Retriever, Labrador, and Rottweiler milk ranged from 1.56 to $2.86 \mathrm{~g} / 100 \mathrm{~mL}$, which was significantly lower than that of bovine and caprine milk $(p<0.05)$. The lactose content of Caucasian Sheepdog milk $(3.92 \mathrm{~g} / 100 \mathrm{~mL})$ was similar to that of bovine $(3.71 \mathrm{~g} / 100 \mathrm{~mL})$ and caprine milk $(3.95 \mathrm{~g} / 100 \mathrm{~mL})$.

\subsection{Protein Profiles of Bovine, Caprine, and Canine Milk by SDS-PAGE}

The protein profiles of canine, bovine, and caprine milk were determined by SDSPAGE (Figure 1). The profiles of bovine and caprine milk (Figure 1, lane 2 and 3) were equivalent to those reported by $\mathrm{Ha}$ et al. [30]. Milk proteins from four breeds of canines also showed good separation. Proteins observed in Figure 1 included $\alpha_{\mathrm{s} 2}$-casein $\left(\alpha_{\mathrm{s} 2}-\mathrm{CN}\right), \alpha_{\mathrm{s} 1}$-casein $\left(\alpha_{\mathrm{s} 1}-\mathrm{CN}\right), \beta$-casein $(\beta-\mathrm{CN}), \mathrm{k}$-casein $(\kappa-\mathrm{CN}), \alpha$-lactalbumin $(\alpha-\mathrm{LA})$, 
$\beta$-lactoglobulin ( $\beta$-LG), lysozyme, and serum albumin. The molecular weight of casein ranged from 19 to $35 \mathrm{kDa}$.

Table 1. The chemical composition of canine, bovine, and caprine milk (g/100 mL).

\begin{tabular}{ccccccc}
\hline Nutrient & Holstein & Saanen & $\begin{array}{c}\text { Golden } \\
\text { Retriever }\end{array}$ & Labrador & $\begin{array}{c}\text { Caucasian } \\
\text { Sheepdog }\end{array}$ & Rottweiler \\
\hline Moisture & $88.64 \pm 0.11^{\mathrm{a}}$ & $87.62 \pm 0.1^{\mathrm{a}}$ & $79.41 \pm 0.16^{\mathrm{b}}$ & $78.45 \pm 0.65^{\mathrm{b}}$ & $78.79 \pm 0.08^{\mathrm{b}}$ & $64.97 \pm 0.47^{\mathrm{c}}$ \\
Dry matter & $11.36 \pm 0.11^{\mathrm{a}}$ & $12.38 \pm 0.1^{\mathrm{a}}$ & $20.59 \pm 0.16^{\mathrm{b}}$ & $22.23 \pm 1.73^{\mathrm{c}}$ & $21.21 \pm 0.08^{\mathrm{bc}}$ & $35.03 \pm 0.47^{\mathrm{d}}$ \\
Crude protein & $3.12 \pm 0.14^{\mathrm{a}}$ & $3.09 \pm 0.05^{\mathrm{a}}$ & $7.57 \pm 0.5^{\mathrm{b}}$ & $8.34 \pm 0.06^{\mathrm{c}}$ & $6.62^{\mathrm{a}} \pm 0.06^{\mathrm{d}}$ & $17.34 \pm 0.28^{\mathrm{e}}$ \\
Fat & $3.71 \pm 0.24^{\mathrm{a}}$ & $4.45 \pm 0.31^{\mathrm{b}}$ & $8.92 \pm 0.17^{\mathrm{c}}$ & $9.94 \pm 0.52^{\mathrm{d}}$ & $9.56 \pm 0.28^{\mathrm{d}}$ & $14.31 \pm 0.29^{\mathrm{e}}$ \\
Ash & $0.82 \pm 0.01^{\mathrm{a}}$ & $0.88 \pm 0.02^{\mathrm{a}}$ & $1.23 \pm 0.04^{\mathrm{c}}$ & $1.19 \pm 0.08^{\mathrm{bc}}$ & $1.11 \pm 0.04^{\mathrm{b}}$ & $1.81 \pm 0.05^{\mathrm{d}}$ \\
Lactose & $3.71 \pm 0.25^{\mathrm{a}}$ & $3.95 \pm 0.38^{\mathrm{a}}$ & $2.86 \pm 0.64^{\mathrm{ab}}$ & $2.76 \pm 1.53^{\mathrm{ab}}$ & $3.92 \pm 0.33^{\mathrm{a}}$ & $1.56 \pm 0.33^{\mathrm{b}}$ \\
\hline
\end{tabular}

Values within each row with different superscripts were significantly different $(p<0.05)$. Data are presented as the mean \pm standard deviation, $n=3$.
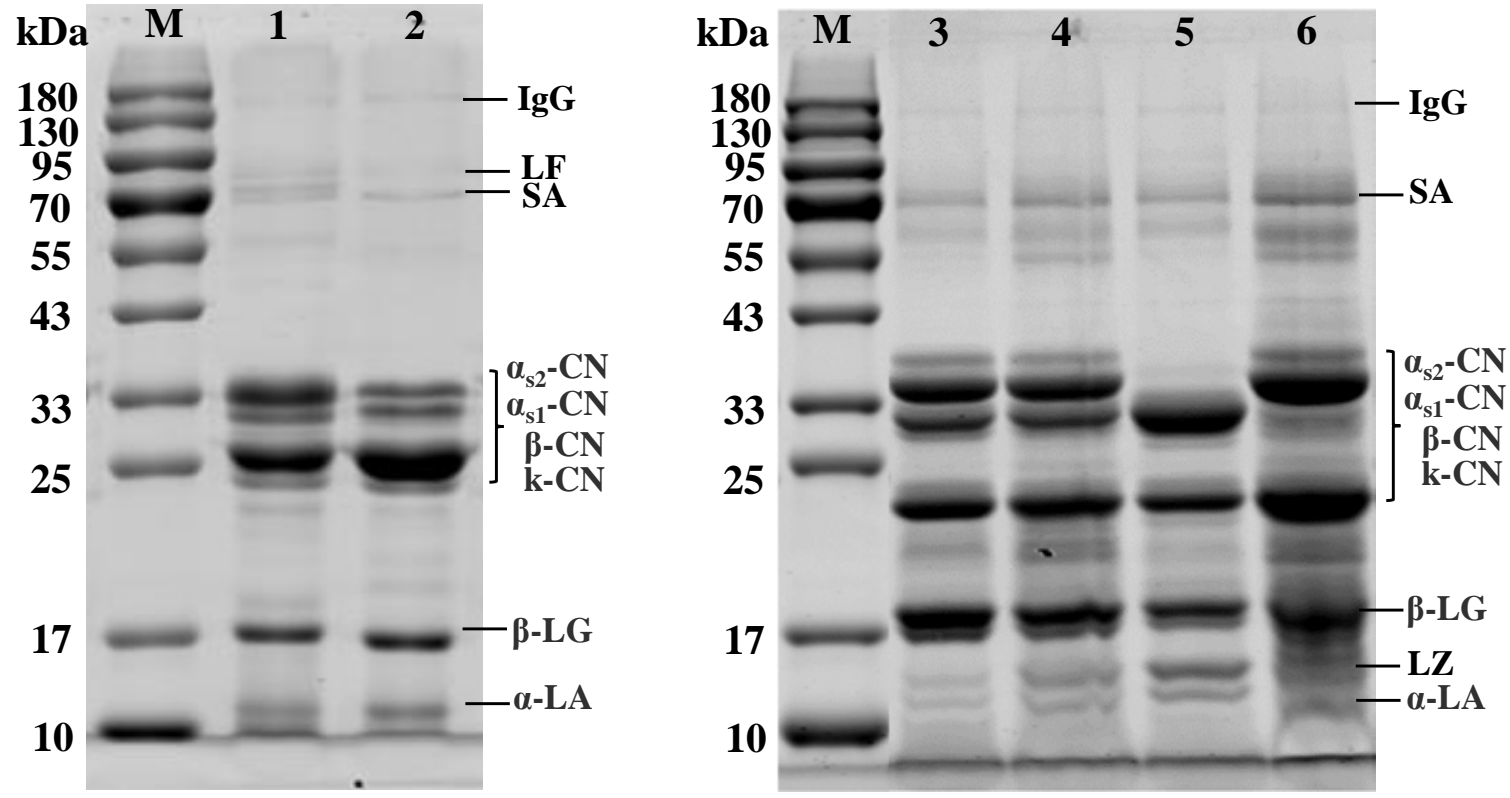

Figure 1. SDS-PAGE analysis of canine, bovine, and caprine milk. Lanes: M: Prestained protein molecular weight marker, (1) Holstein, (2) Saanen, (3) Golden Retriever, (4) Labrador, (5) Caucasian Sheepdog, (6) Rottweiler. LF: Lactoferrin, SA: Serum albumin, $\beta$-LG: $\beta$-lactoglobulin, LZ: Lysozyme, $\alpha$-LA: $\alpha$-lactalbumin, IgG: Immunoglobulin G, $\alpha_{\mathrm{s} 1}-\mathrm{CN}$ : $\alpha_{\mathrm{s} 1}$-casein, $\alpha_{\mathrm{s} 2}-\mathrm{CN}$ : $\alpha_{\mathrm{s} 2}$-casein, $\beta$-CN: $\beta$-casein, $k-C N$ : $k$-casein.

As shown in Figure 1, the distribution of whey proteins in canine milk was similar to that in bovine and caprine milk. A significant lysozyme band was observed in canine whey, and Halliday et al. [31] also found that the lysozyme content in canine milk was $2.57 \pm 0.27 \mathrm{mg} / \mathrm{mL}$, and there was no significant difference in the amino acid sequence between canine milk and human milk. The bands of lactoferrin in canine milks were weaker than those in bovine and caprine milk. $\beta$-LG was the most pronounced protein in canine whey and seemed to have a higher molecular weight than that of bovine and caprine $\beta$-LG. The $\alpha$-LA band was relatively weak. The $\alpha_{\mathrm{s} 2}-\mathrm{CN}$ band was stronger than that of $\alpha_{\mathrm{s} 1}-\mathrm{CN}$. Compared with bovine milk, the $\alpha_{\mathrm{s} 1}-\mathrm{CN}$ band in canine milk was weaker. The band width of $\beta-\mathrm{CN}$ was smaller than that of bovine and caprine milk. The distribution of the milk proteins, $\beta-\mathrm{CN}, \mathrm{k}-\mathrm{CN}$, and $\alpha$-casein $(\alpha-\mathrm{CN})$ were markedly different in Caucasian Sheepdog milk compared with the other three breeds. 


\subsection{Identification of Proteins in Canine, Bovine, and Caprine Milk by RP-HPLC}

The protein profiles of canine, bovine, and caprine skim milk were determined by RP-HPLC (Figure 2). Canine casein, $\alpha$-LA, and $\beta$-LG showed different separation compared with bovine and caprine milk, which might be due to the hydrophobic interactions of the proteins as well as amino acid composition. The elution profiles of bovine and caprine milk proteins in Figure 2 were consistent with those reported by Bonfatti et al. and Moatsou et al. [21,32].

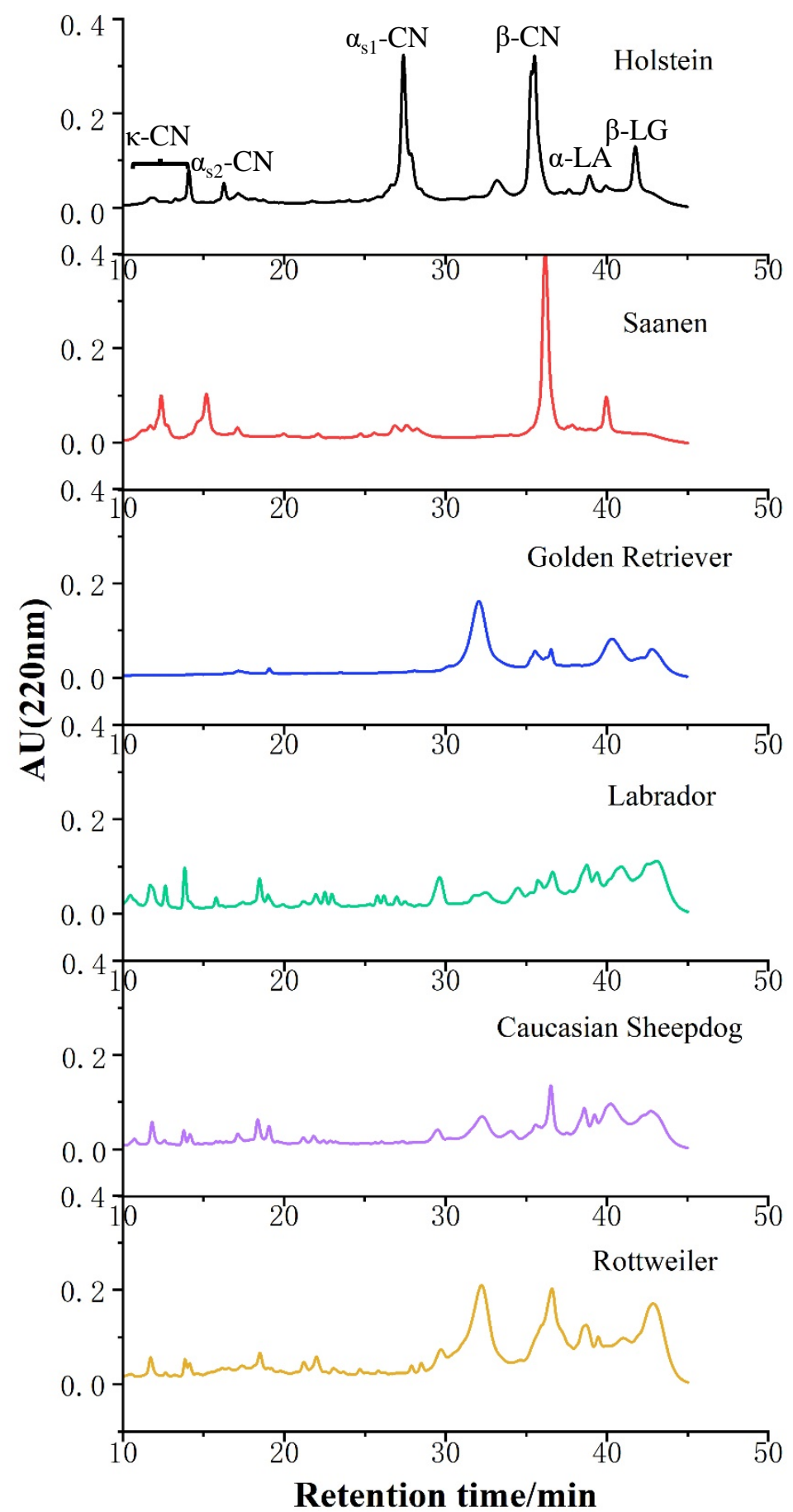

Figure 2. Reverse phase high-performance liquid chromatography chromatograms of protein fractions in canine, bovine, and caprine milk. $\alpha_{\mathrm{s} 1}-\mathrm{CN}: \alpha_{\mathrm{s} 1}$-casein, $\alpha_{\mathrm{s} 2}-\mathrm{CN}: \alpha_{\mathrm{s} 2}$-casein, $\beta-\mathrm{CN}$ : $\beta$-casein, k-CN: k-casein, $\beta$-LG: $\beta$-lactoglobulin, $\alpha$-LA: $\alpha$-lactalbumin. 
The relative proportions of milk proteins were associated with species and lactation stage [33], which were responsible for the differences in the chromatograms. As shown in Figure 2, the milk protein chromatograms of different canine milks were similar, but the k-CN and $\alpha_{\mathrm{s} 2}-\mathrm{CN}$ levels in Golden Retriever milk were not well separated. Because the standards used in this study were bovine casein, the retention time of $\alpha-\mathrm{CN}$ in canine milk shifted compared to bovine and caprine milk. The peak-time ranges of $\alpha_{\mathrm{s} 2}-\mathrm{CN}$ and $\alpha_{\mathrm{s} 1}-\mathrm{CN}$ were 18.12-18.73 $\mathrm{min}$ and 31-33.68 min according to the results of the chromatogram and SDS-PAGE. Differences in the elution time of proteins from different species were attributed to different amino acid compositions and modification of the proteins [34].

The quantification data calculated based on the peak areas of the chromatographic profiles were presented in Table 2. The contents of $\alpha_{\mathrm{s} 1}-\mathrm{CN}, \alpha_{\mathrm{s} 2}-\mathrm{CN}, \beta-\mathrm{CN}, \mathrm{k}-\mathrm{CN}, \beta-\mathrm{LG}$, $\alpha$-LA were the significant differences in canine, bovine, and caprine milk $(p<0.05)$.

Table 2. Concentration of milk proteins of canine, bovine, and caprine milk (mg/mL).

\begin{tabular}{ccccccc}
\hline & Holstein & Saanen & $\begin{array}{c}\text { Golden } \\
\text { Retriever }\end{array}$ & Labrador & $\begin{array}{c}\text { Caucasian } \\
\text { Sheepdog }\end{array}$ & Rottweiler \\
\hline$\alpha_{\mathrm{s} 1}-\mathrm{CN}$ & $9.45 \pm 0.37^{\mathrm{b}}$ & $3.16 \pm 0.44^{\mathrm{a}}$ & $9.67 \pm 0.60^{\mathrm{b}}$ & $4.27 \pm 0.24^{\mathrm{a}}$ & $7.76 \pm 1.04^{\mathrm{b}}$ & $30.98^{\mathrm{a}} \pm 3.95^{\mathrm{c}}$ \\
$\alpha_{\mathrm{s} 2}-\mathrm{CN}$ & $1.86 \pm 0.04^{\mathrm{a}}$ & $7.26 \pm 0.28^{\mathrm{b}}$ & $\mathrm{ND}$ & $4.83 \pm 0.78^{\mathrm{c}}$ & $4.30 \pm 0.43^{\mathrm{c}}$ & $6.73 \pm 0.63^{\mathrm{b}}$ \\
$\beta-\mathrm{CN}$ & $6.59 \pm 0.31^{\mathrm{a}}$ & $9.19 \pm 0.66^{\mathrm{b}}$ & $2.27 \pm 0.83^{\mathrm{c}}$ & $5.19 \pm 0.46^{\mathrm{d}}$ & $6.50 \pm 0.49^{\mathrm{a}}$ & $17.26^{\mathrm{a}} \pm 0.17^{\mathrm{e}}$ \\
$\mathrm{K}-\mathrm{CN}$ & $3.20 \pm 0.02^{\mathrm{a}}$ & $5.74 \pm 0.16^{\mathrm{b}}$ & $\mathrm{ND}$ & $\mathrm{ND}$ & $\mathrm{ND}$ & $\mathrm{ND}$ \\
$\beta-\mathrm{LG}$ & $3.35 \pm 0.82^{\mathrm{a}}$ & $2.79 \pm 0.76^{\mathrm{a}}$ & $7.84 \pm 1.25^{\mathrm{b}}$ & $12.56 \pm 3.11^{\mathrm{d}}$ & $11.5 \pm 0.73^{\mathrm{cd}}$ & $8.69 \pm 0.88^{\mathrm{bc}}$ \\
$\alpha-\mathrm{LA}$ & $0.78 \pm 0.18^{\mathrm{a}}$ & $0.67 \pm 0.07^{\mathrm{a}}$ & $0.92 \pm 0.10^{\mathrm{a}}$ & $4.08 \pm 0.18^{\mathrm{b}}$ & $3.59 \pm 0.35^{\mathrm{c}}$ & $4.99 \pm 0.49^{\mathrm{d}}$ \\
\hline
\end{tabular}

Values within each row with different superscripts are significantly different $(p<0.05)$. Data are presented as the mean \pm standard deviation, $n=3$. $\alpha_{\mathrm{s} 1}$-CN: $\alpha_{\mathrm{s} 1}$-casein, $\alpha_{\mathrm{s} 2}-\mathrm{CN}: \alpha_{\mathrm{s} 2}$-casein, $\beta$-CN: $\beta$-casein, $\mathrm{k}$-CN: $\mathrm{k}$-casein, $\beta$-LG: $\beta$-lactoglobulin, $\alpha$-LA: $\alpha$-lactalbumin. ND = Not detected.

The content of $\mathrm{k}-\mathrm{CN}$ in canine milk could not be estimated due to a shift in elution profile, and four variants of $\mathrm{k}-\mathrm{CN}$ have been identified in bovine milk. $\alpha_{\mathrm{s} 1}-\mathrm{CN}$ is the major casein in canine casein, followed by $\beta-\mathrm{CN}$. There was a significantly higher content of $\beta$-LG and $\alpha$-LA in canine whey protein than in bovine and caprine milk. $\alpha_{\mathrm{s} 1}-\mathrm{CN}$ and $\beta$-LG in bovine milk are major factors in infant allergy, whereas the surface hydrophobic amino acids of $\beta$-LG in caprine milk are easier to decompose, explaining why caprine milk has lower sensitization and higher digestibility than bovine milk [35-37]. However, the role of these protein components in puppies remains to be investigated and analyzed.

\subsection{The Fatty Acid Profile Composition of Canine, Bovine, and Caprine Milk}

The compositions and contents of FAs in different milk samples are shown in Table 3. The fatty acid profiles were significantly different between the milk samples $(p<0.05)$. In ruminant milk, approximately half of the long-chain FAs ( $\geq$ C18) were derived from the diet. The majority of smaller C4:0-C14:0 FAs originate from the de novo FA synthesis in the mammary gland, but $\mathrm{C} 16$ can be synthesized from the diet and the mammary glands [38]. The unsaturated fatty acid content, especially C6-C12 FAs in canine milk, was lower than that in bovine and caprine milk. Palmitic acid (C16:0) was the most abundant saturated fatty acid accounting for $38.5 \%, 36.71 \%$, and $30.03-33.96 \%$ in bovine, caprine, and canine milk, respectively. There was no significant difference in palmitic acid content between the different breeds of $\operatorname{dog}(p>0.05)$, except for Rottweiler. Among saturated fatty acids (SFAs), the content of short chain fatty acids (C4-C8) and medium-long chain fatty acids (C10-C20) in canine milk were lower than those of bovine and caprine milk. It was reported that short chain fatty acids play a major role in infant health by regulating lipid metabolism, and intestinal flora by adjusting the intestinal $\mathrm{pH}[39,40]$. 
Table 3. Fatty acid profiles of canine, bovine, and caprine milk (g/100 g total fatty acid).

\begin{tabular}{|c|c|c|c|c|c|c|}
\hline & Holstein & Saanen & Golden Retriever & Labrador & Caucasian Sheepdog & Rottweiler \\
\hline C4:0 & $0.48 \pm 0.11^{\mathrm{a}}$ & $0.64 \pm 0.19^{a}$ & $0.25 \pm 0.08^{b}$ & $0.24 \pm 0.04^{b}$ & $0.26 \pm 0.11^{b}$ & $0.15 \pm 0.06^{b}$ \\
\hline C6:0 & $0.94 \pm 0.18^{a b}$ & $2.06 \pm 0.31^{\mathrm{c}}$ & $0.76 \pm 0.04^{a b}$ & $0.82 \pm 0.1 \mathrm{ab}$ & $0.62 \pm 0.06^{\mathrm{a}}$ & $1.01 \pm 0.25^{b}$ \\
\hline $\mathrm{C} 10: 0$ & $0.78 \pm 0.04^{b}$ & $2.43 \pm 0.48^{\mathrm{a}}$ & $0.30 \pm 0.1^{c}$ & $0.17 \pm 0.03^{c}$ & $0.43 \pm 0.03 b c$ & $0.19 \pm 0.03^{c}$ \\
\hline $\mathrm{C} 12: 0$ & $2.29 \pm 0.08^{a}$ & $2.94 \pm 0.21^{b}$ & $0.31 \pm 0.02^{d}$ & $0.09 \pm 0.01^{\mathrm{e}}$ & $0.69 \pm 0.03^{c}$ & $0.10 \pm 0.02^{\mathrm{e}}$ \\
\hline $\mathrm{C} 14: 0$ & $13.36 \pm 0.6^{\mathrm{a}}$ & $13.93 \pm 0.54^{\mathrm{a}}$ & $3.25 \pm 0.08^{c}$ & $3.23 \pm 0.7^{c}$ & $5.28 \pm 0.14^{b}$ & $1.63 \pm 0.06^{\mathrm{d}}$ \\
\hline $\mathrm{C} 14: 1$ & $0.68 \pm 0.04^{\mathrm{a}}$ & $0.28 \pm 0.05^{\mathrm{b}}$ & $0.08 \pm 0.01^{c}$ & $0.12 \pm 0.06^{c}$ & $0.16 \pm 0.01^{c}$ & ND \\
\hline $\mathrm{C} 16: 0$ & $38.50 \pm 0.87^{\mathrm{a}}$ & $36.71 \pm 0.93 \mathrm{ab}$ & $33.96 \pm 0.7^{\mathrm{ab}}$ & $32.39 \pm 7.88^{a b}$ & $32.68 \pm 5.58^{\mathrm{ab}}$ & $30.03 \pm 5.03^{b}$ \\
\hline $\mathrm{C} 16: 1$ & ND & ND & $2.28 \pm 0.17^{a}$ & $4.11 \pm 0.16^{\mathrm{b}}$ & $1.77 \pm 0.08^{c}$ & $3.36 \pm 0.02^{d}$ \\
\hline $\mathrm{C} 17: 0$ & $1.47 \pm 0.01^{\mathrm{a}}$ & $1.01 \pm 0.04^{b}$ & $0.41 \pm 0.07^{c}$ & $0.40 \pm 0.04^{c}$ & $0.42 \pm 0.02^{c}$ & $0.43 \pm 0.03^{c}$ \\
\hline C18:0 & $11.76 \pm 0.07 \mathrm{bc}$ & $12.15 \pm 0.76^{c}$ & $12.03 \pm 0.83^{c}$ & $12.15 \pm 1.88^{c}$ & $9.50 \pm 1.41^{\mathrm{a}}$ & $9.86 \pm 0.76^{\mathrm{ab}}$ \\
\hline C18:1n9t & $5.30 \pm 0.57^{\mathrm{a}}$ & $0.46 \pm 0.11^{b}$ & $12.81 \pm 1.58^{\mathrm{d}}$ & $11.12 \pm 1.09 \mathrm{~cd}$ & $9.27 \pm 1.50^{c}$ & $11.59 \pm 2.17^{\mathrm{cd}}$ \\
\hline $\mathrm{C} 18: \ln 9 \mathrm{c}$ & $20.24 \pm 0.18^{a b}$ & $23.03 \pm 0.59^{a}$ & $14.52 \pm 2.54^{c}$ & $16.88 \pm 4.82^{b c}$ & $17.15 \pm 0.51^{b c}$ & $17.69 \pm 3.35 \mathrm{bc}$ \\
\hline C18:2n6t & ND & ND & $0.21 \pm 0.13^{\mathrm{a}}$ & $0.43 \pm 0.23^{\mathrm{a}}$ & $0.17 \pm 0.05^{\mathrm{a}}$ & $0.33 \pm 0.03^{a}$ \\
\hline $\mathrm{C} 18 \mathrm{2} 2 \mathrm{n} 6 \mathrm{c}$ & $1.32 \pm 0.06^{\mathrm{a}}$ & $1.08 \pm 0.25^{\mathrm{a}}$ & $11.79 \pm 2.03^{b}$ & $11.24 \pm 4.56^{\mathrm{b}}$ & $13.58 \pm 1.19^{b}$ & $15.41 \pm 2.79^{b}$ \\
\hline C20:0 & $0.39 \pm 0.09^{b}$ & $0.73 \pm 0.11^{\mathrm{c}}$ & $0.19 \pm 0.01^{\mathrm{a}}$ & $0.21 \pm 0.10^{\mathrm{ab}}$ & $1.09 \pm 0.16^{\mathrm{d}}$ & $0.20 \pm 0.05^{\mathrm{a}}$ \\
\hline C18:3n6 & $0.11 \pm 0.02^{\mathrm{a}}$ & $0.16 \pm 0.02^{\mathrm{a}}$ & $0.26 \pm 0.11^{\mathrm{a}}$ & $0.32 \pm 0.01$ & $1.48 \pm 0.47^{b}$ & $0.32 \pm 0.05^{\mathrm{a}}$ \\
\hline C20:1 & $0.17 \pm 0.02^{\mathrm{a}}$ & $0.11 \pm 0.02^{a}$ & $0.24 \pm 0.06^{\mathrm{a}}$ & $0.59 \pm 0.11^{b}$ & $0.50 \pm 0.08^{\mathrm{b}}$ & $0.56 \pm 0.08^{\mathrm{b}}$ \\
\hline $\mathrm{C} 18: 3 \mathrm{n} 3$ & $0.30 \pm 0.07^{\mathrm{cd}}$ & $0.60 \pm 0.02^{\mathrm{e}}$ & $0.19 \pm 0.01 \mathrm{bc}$ & $0.09 \pm 0.06^{\mathrm{a}}$ & $0.08 \pm 0.02^{\mathrm{ab}}$ & $0.40 \pm 0.03^{d}$ \\
\hline C21:0 & ND & $0.20 \pm 0.11^{\mathrm{a}}$ & $1.38 \pm 0.84^{b}$ & $0.66 \pm 0.03^{a b}$ & $0.76 \pm 0.05^{\mathrm{ab}}$ & $0.91 \pm 0.15^{\mathrm{ab}}$ \\
\hline C20:3 & ND & ND & $0.46 \pm 0.06^{\mathrm{a}}$ & $0.53 \pm 0.24^{\mathrm{a}}$ & $0.66 \pm 0.04^{a b}$ & $0.83 \pm 0.11^{b}$ \\
\hline C22:1 & $0.20 \pm 0.01^{\mathrm{a}}$ & $0.36 \pm 0.08^{a b}$ & $0.56 \pm 0.05^{b}$ & $1.17 \pm 0.25^{c}$ & $1.34 \pm 0.01^{c}$ & $0.51 \pm 0.12^{b}$ \\
\hline $\mathrm{C} 24: 1 \mathrm{n} 9$ & $0.07 \pm 0.01^{\mathrm{a}}$ & ND & $0.02 \pm 0.01^{b}$ & ND & $0.01 \pm 0.00^{c}$ & $0.08 \pm 0.05^{\mathrm{a}}$ \\
\hline C20:4 & $0.24 \pm 0.17^{\mathrm{a}}$ & ND & $0.82 \pm 0.28^{b}$ & $1.77 \pm 0.42^{c}$ & $1.29 \pm 0.14^{b c}$ & $1.43 \pm 0.23^{c}$ \\
\hline C20:5 & $0.1 \pm 0.01^{\mathrm{a}}$ & $0.13 \pm 0.01^{\mathrm{a}}$ & $0.82 \pm 0.13^{b}$ & $0.99 \pm 0.05^{c}$ & $0.08 \pm 0.02^{\mathrm{a}}$ & $0.15 \pm 0.02^{\mathrm{a}}$ \\
\hline C24:0 & $0.23 \pm 0.08^{\mathrm{a}}$ & ND & ND & ND & $0.07 \pm 0.01^{b}$ & ND \\
\hline $\mathrm{C} 22: 6$ & ND & ND & ND & $0.43 \pm 0.07^{\mathrm{a}}$ & $0.12 \pm 0.01^{b}$ & $0.35 \pm 0.02^{\mathrm{a}}$ \\
\hline & & & Sums of fatty acids & & & \\
\hline SFA & $70.30 \pm 0.56^{\mathrm{a}}$ & $72.99 \pm 2.3^{\mathrm{a}}$ & $53.18 \pm 2.4^{b}$ & $50.32 \pm 10.20^{b}$ & $51.49 \pm 4.8^{b}$ & $47.57 \pm 2.6^{b}$ \\
\hline MUFA & $26.61 \pm 0.85^{\mathrm{ab}}$ & $24.10 \pm 0.27^{\mathrm{a}}$ & $29.71 \pm 2.61 b c$ & $32.95 \pm 3.94^{c}$ & $30.2 \pm 1.10^{b c}$ & $32.63 \pm 2.44^{\mathrm{c}}$ \\
\hline PUFA & $2.91 \pm 0.17^{\mathrm{a}}$ & $2.90 \pm 0.38^{\mathrm{a}}$ & $17.07 \pm 2.52^{b}$ & $16.83 \pm 4.43^{b}$ & $18.19 \pm 0.45^{b}$ & $20.56 \pm 3.30^{b}$ \\
\hline n-6 & $1.69 \pm 0.13^{\mathrm{a}}$ & $1.25 \pm 0.27^{\mathrm{a}}$ & $13.07 \pm 2.19^{b}$ & $13.59 \pm 4.37^{b}$ & $15.96 \pm 0.27^{b}$ & $17.49 \pm 3.11^{b}$ \\
\hline$n-3$ & $0.40 \pm 0.05^{\mathrm{a}}$ & $0.72 \pm 0.01^{\mathrm{ab}}$ & $1.40 \pm 0.07 \mathrm{bc}$ & $1.70 \pm 0.71^{\mathrm{c}}$ & $0.90 \pm 0.03^{\mathrm{ab}}$ & $1.71 \pm 0.78^{c}$ \\
\hline
\end{tabular}

Values within each row with different superscripts are significantly different $(p<0.05)$. Data are presented as the mean \pm standard deviation, $n=3$. SFA: saturated fatty acid, MUFA monounsaturated fatty acid, PUFA: polyunsaturated fatty acid, n-6: omega-6 fatty acid (C18:2n-6 + C20:4n-6 + C18:3n-6), n-3: omega-3 fatty acid (C18:3n-3 + C20:5n-3 + C22:6n-3) ND = Not detected. 
The proportions of monounsaturated fatty acids (MUFAs) in bovine, caprine, and canine milk were $26.61 \%, 24.1 \%$, and $29.71-32.95 \%$, respectively, which were significantly different $(p<0.05)$. Oleic acid (C18:1) was the predominant MUFA in milk samples, which was an important source of energy for breast-fed infant [41,42]. The same result was found in canine milk (27.33-29.28\%). Polyunsaturated fatty acids (PUFAs), especially n-3 and n-6 PUFAs, in canine milk were significantly higher than in bovine and caprine milk $(p<0.05)$. Regarding n-6 PUFAs, linoleic (C18:2, LA) was dominant in breast milk, followed by arachidonic acid (C20:4, ARA). Koletzko et al. [43] reported that docosahexaenoic acid (C22:6n-3, DHA) and ARA were the main components of membrane phospholipids, and play important roles in infant retinal, brain, platelet, and immune system development. Bauer et al. [44] found that puppies fed with a supplement of long chain n-3 fatty acids (EPA and DHA) had better vision than those fed on a non-supplemented control diet. Zicker et al. [45] reported that puppies fed with DHA after weaning had better learning, cognitive ability, and memory, as well as improved immunity and retinal function.

\subsection{Mineral Contents in Canine, Bovine, and Caprine Milk}

Minerals regulate the biochemical cells of the body, and an excess or deficiency of minerals is harmful to the health and production of livestock [46]. The mineral content of different milk samples is shown in Table 4. The contents of $\mathrm{Mg}, \mathrm{Na}, \mathrm{Fe}, \mathrm{Zn}, \mathrm{Cu}, \mathrm{Mn}$, and Se in canine milk were higher than in bovine and caprine milk, but the content of $\mathrm{K}$ was significantly lower $(p<0.05)$. Haenlein et al. [47] reported that caprine milk had similar contents of $\mathrm{Na}, \mathrm{Fe}, \mathrm{Zn}$, and $\mathrm{Mn}$ to bovine milk, but a higher content of $\mathrm{Ca}, \mathrm{K}, \mathrm{Mg}, \mathrm{P}$, and $\mathrm{Cl}$.

Table 4. The mineral contents of canine, bovine, and caprine milk (mg/100 mL).

\begin{tabular}{|c|c|c|c|c|c|c|}
\hline & Holstein & Saanen & Golden Retriever & Labrador & Caucasian Sheepdog & Rottweiler \\
\hline $\mathrm{Mg}$ & 9.63 & 14.3 & 12.8 & 13 & 9.85 & 32.9 \\
\hline K & 126.2 & 152.1 & 76.9 & 104.8 & 113.3 & 189.4 \\
\hline $\mathrm{Na}$ & 49.9 & 60.6 & 104.5 & 110.2 & 80.7 & 92.1 \\
\hline $\mathrm{Fe}$ & ND & ND & ND & 0.405 & 0.58 & 0.749 \\
\hline $\mathrm{Zn}$ & 0.31 & 0.394 & 1.34 & 1.13 & 0.85 & 0.854 \\
\hline $\mathrm{Cu}$ & ND & ND & 0.047 & 0.119 & 0.046 & 0.398 \\
\hline $\operatorname{Mn}(\mu \mathrm{g} / 100 \mathrm{~mL})$ & ND & ND & 10.6 & 11.7 & 16.6 & 10.6 \\
\hline Se $(\mu \mathrm{g} / 100 \mathrm{~mL})$ & 2.36 & 1.06 & 10.6 & 11 & 10 & 39.2 \\
\hline
\end{tabular}

$\mathrm{ND}=$ Not detected .

There were significant differences in mineral composition between different canine milk samples $(p<0.05)$. K, Fe, $\mathrm{Zn}, \mathrm{Cu}$, and Se content in Rottweiler milk was significantly higher than in Golden Retriever, Labrador, and Caucasian Sheepdog milk. According to Table 4, K (76.9-113.3 mg/100 mL) content in canine milk was the most abundant mineral, followed by $\mathrm{Na}(80.7-110.2 \mathrm{mg} / 100 \mathrm{~mL})$. The contents of $\mathrm{Zn}(0.85-1.34 \mathrm{mg} / 100 \mathrm{~mL})$ and $\mathrm{Mg}$ (9.85-13 mg/100 mL) were higher, the content of $\mathrm{Cu}(0.046-0.119 \mathrm{mg} / 100 \mathrm{~mL})$ was lower, and the content of Fe $(0.405-0.749 \mathrm{mg} / 100 \mathrm{~mL})$ was similar in this study compared with the results reported by Anderson et al. [48]. Differences in mineral content in canine milk may be related to breed, feed, lactation stage, or different analysis methods.

\section{Conclusions}

There were differences in the nutrient profiles of canine milk compared with bovine and caprine milk. The nutrient contents in four canine milk samples were different, and the milk obtained from the Rottweiler had the highest density of nutrients. Canine milk had higher protein, fat, and ash content, and lower lactose content than bovine and caprine milk. The protein profile of canine milk was similar to bovine and caprine milk, but the protein content was considerably different. Canine milk had higher levels of unsaturated fatty acids including the essential fatty acids LA, ARA, DHA, and lower proportions of SFAs than bovine and caprine milk. Canine milk contained more minerals than bovine and 
caprine milk. This study may provide useful information about the composition of canine milk and may provide insights for the development of canine milk substitute formulations.

Author Contributions: Conceptualization, M.G., M.Z., X.S. and J.C.; methodology and investigation, M.Z., X.S. and J.C., formal analysis, M.Z.; data curation, M.Z., X.S. and J.C., writing-original draft preparation, M.Z., writing - review and editing, M.G., X.S. and J.C. supervision, X.S. and J.C. project administration, M.G. All authors have read and agreed to the published version of the manuscript.

Funding: This research received no external funding.

Institutional Review Board Statement: Not applicable.

Informed Consent Statement: Not applicable.

Data Availability Statement: The datasets generated for this study are available on request to the corresponding author.

Acknowledgments: This project was financially supported by a special grant from the Northeast Agricultural University, Harbin, China.

Conflicts of Interest: The authors declare no conflict of interest.

\section{References}

1. Nakamura, T.; Urashima, T.; Mizukami, T.; Fukushima, M.; Arai, I.; Senshu, T.; Imazu, K.; Nakao, T.; Saito, T.; Ye, Z.; et al. Composition and oligosaccharides of a milk sample of the giant panda, Aduropoda melanoleuca. Comp. Biochem. Physiol. Part B 2003, 135, 439-448. [CrossRef]

2. Tonini, B.; Fusi, E.; Rizzi, R.; Bontempo, V. Nucleotides in canine colostrum and milk at different stages of lactation. Arch. Anim. Nutr. 2010, 64, 337-341. [CrossRef]

3. Field, M.C. The immunological components of human milk and their effect on immune development in infant. J. Nutr. 2005, 135, 1-4. [CrossRef] [PubMed]

4. Boza, J.; Sanz Sampelayo, M.R. Aspectos nutricionales de la leche de cabra. Ann. Acad. Cienc. Vet. Andal. Oriental. 1997, 10, 109-139.

5. Corbee, R.J.; Tryfonidou, M.A.; Beckers, I.P.; Hazewinkel, H.A. Composition and use of puppy milk replacers in german shepherd puppies in the netherlands. J. Anim. Physiol. Anim. Nutr. 2012, 96, 395-402. [CrossRef] [PubMed]

6. Debraekeleer, J. Comparative analysis of milk replacers for puppies and kittens. J. Anim. Physiol. Anim. Nutr. 1998, 80, 185-193. [CrossRef]

7. Macias Rostami, S.; Benet, T.; Spears, J.; Reynolds, A.; Satyaraj, E.; Sprenger, N.; Austin, S. Milk oligosaccharides over time of lactation from different dog breeds. PLoS ONE 2014, 9, e99824. [CrossRef] [PubMed]

8. Mila, H.; Feugier, A.; Grellet, A.; Anne, J.; Gonnier, M.; Martin, M.; Rossig, L.; Chastant-Maillard, S. Immunoglobulin G concentration in canine colostrum: Evaluation and variability. J. Reprod. Immunol. 2015, 112, 24-28. [CrossRef]

9. Wrigglesworth, D.J.; Goonatilleke, E.; Haydock, R.; Hughes, K.R.; Lebrilla, C.B.; Swanson, K.S.; Jones, P.; Watson, P. Highthroughput glycomic analyses reveal unique oligosaccharide profiles of canine and feline milk samples. PLoS ONE 2020, 15, e0243323. [CrossRef]

10. Barlowska, J.; Szwajkowska, M.; Litwinczuk, Z.; Krol, J. Nutritional value and technological suitability of milk from various animal species used for dairy production. Compr. Rev. Food Sci. Food Saf. 2011, 10, 291-302. [CrossRef]

11. Giffard, C.; Seino, M.; Markwell, P.; Bektash, R. Benefits of bovine colostrum on fecal quality in recently weaned puppies. J. Nutr. 2004, 134, 2126S-2127S. [CrossRef]

12. Satyaraj, E.; Reynolds, A.; Pelker, R.; Labuda, J.; Zhang, P.; Sun, P. Supplementation of diets with bovine colostrum influences immune function in dogs. Br. J. Nutr. 2013, 110, 2216-2221. [CrossRef] [PubMed]

13. Hall, E.J. Gastrointestinal aspects of food allergy: A review. J. Small Anim. Pract. 2008, 35, 145-152. [CrossRef]

14. Zhang, H.; Yao, J.; Zhao, D.; Liu, H.; Li, J.; Guo, M. Changes in Chemical Composition of Alxa Bactrian Camel Milk During Lactation. J. Dairy Sci. 2005, 88, 3402-3410. [CrossRef]

15. IDF 105E; Milk-Determination of Fat Content. IDF: Schaerbeek, Belgium, 2008.

16. IDF 021B; Milk, Cream and Evaporated Milk-Determination of Total Solids Content (Reference Method). IDF: Schaerbeek, Belgium, 1987.

17. IDF 027; Determination of the Ash Content of Processed Cheese Products. IDF: Schaerbeek, Belgium, 1964.

18. Wang, H.; Sun, X.; Song, X.; Guo, M. Effects of kefir grains from different origins on proteolysis and volatile profile of goat milk kefir. Food Chem. 2021, 339, 128099. [CrossRef]

19. Bonizzi, I.; Buffoni, J.N.; Feligini, M. Quantification of bovine casein fractions by direct chromatographic analysis of milk. Approaching the application to a real production context. J. Chromatogr. A 2009, 1216, 165-168. [CrossRef]

20. Bobe, G.; Beitz, D.C.; Freeman, A.E.; Lindberg, G.L. Separation and Quantification of Bovine Milk Proteins by Reversed-Phase High-Performance Liquid Chromatography. J. Agric. Food Chem. 1998, 46, 458-463. [CrossRef] 
21. Bonfatti, V.; Grigoletto, L.; Cecchinato, A.; Gallo, L.; Carnier, P. Validation of a new reversed-phase high-performance liquid chromatography method for separation and quantification of bovine milk protein genetic variants. J. Chromatogr.A 2008, 1195, 101-106. [CrossRef] [PubMed]

22. Wang, L.; Li, X.; Liu, L.; da Zhang, H.; Zhang, Y.; Hao Chang, Y.; Zhu, Q.P. Comparative lipidomics analysis of human, bovine and caprine milk by UHPLC-Q-TOF-MS. Food Chem. 2020, 310, 125865. [CrossRef]

23. GB 5009.93; National Food Safety Standard. Determination of Multi-Element in Foods. GB: Beijing, China, 2003.

24. Park, Y.W. Rheological characteristics of goat and sheep milk. Small Rumin. Res. 2007, 68, 73-87. [CrossRef]

25. Heinze, C.; Freeman, L.; Martin, C.; Power, M.; Fascetti, A. Comparison of the nutrient composition of commercial dog milk replacers with that of dog milk. J. Am. Vet. Med. A 2014, 244, 1413-1422. [CrossRef]

26. Oftedal, O. Lactation in the Dog milk composition and intake by Puppies. J. Nutr. 1984, 114, 803-812. [CrossRef] [PubMed]

27. Baines, F.M. Milk substitutes and the hand rearing of orphan puppies and kittens. J. Small Anim. Pract. 2010, $22,555-578$.

28. Molinari, C.E.; Casadio, Y.S.; Hartmann, B.T.; Livk, A.; Bringans, S.; Arthur, P.G.; Hartmann, P.E. Proteome mapping of human skim milk proteins in term and preterm milk. J. Proteome Res. 2012, 11, 1696-1714. [CrossRef] [PubMed]

29. Emmett, P.M.; Rogers, I.S. Properties of human milk and their relationship with maternal nutrition. Early Hum. Dev. 1997, 49, S7-S28. [CrossRef]

30. Ha, M.; Bekhit, A.E.-D.; McConnell, M.; Mason, S.; Carne, A. Fractionation of whey proteins from red deer (Cervus elaphus) milk and comparison with whey proteins from cow, sheep and goat milks. Small Rumin. Res. 2014, 120, 125-134. [CrossRef]

31. Halliday, J.A.; Bell, K.; Shaw, D.C. Feline and canine milk lysozymes. Comp. Biochen. Phys. B 1993, 106, 859-865. [CrossRef]

32. Moatsou, G.; Moschopoulou, E.; Mollé, D.; Gagnaire, V.; Kandarakis, I.; Léonil, J. Comparative study of the protein fraction of goat milk from the Indigenous greek breed and from international breeds. Food Chem. 2008, 106, 509-520. [CrossRef]

33. Landete-Castillejos, T.; Garcia, A.; Molina, P.; Vergara, H.; Garde, J.; Gallego, L. Milk production and composition in captive iberian red deer (Cervus elaphus hispanicus) effect of birth date. J. Anim. Sci. 2000, 78, 2771. [CrossRef] [PubMed]

34. Jenness, R. Comparative aspects of milk proteins. J. Dairy Res. 1979, 46, 197-210. [CrossRef]

35. Park, Y. Hypo-allergenic and therapeutic significance of goat milk. Small Rumin. Res. 1994, 14, 151-159. [CrossRef]

36. Lara-Villoslada, F.; Olivares, M.; Jimenez, J.; Boza, J.; Xaus, J. Goat milk is less immunogenic than cow milk in a murine model of atopy. J. Pediatr. Gastr. Nutr. 2004, 39, 354-360. [CrossRef]

37. El-Zahar, K.; Sitohy, M.; Choiset, Y.; Métro, F.; Haertlé, T.; Chobert, J.-M. Peptic hydrolysis of ovine $\beta$-lactoglobulin and $\alpha$-lactalbumin exceptional susceptibility of native ovine $\beta$-lactoglobulin to pepsinolysis. Int. Dairy J. 2005, 15, 17-27. [CrossRef]

38. Yurchenko, S.; Sats, A.; Tatar, V.; Kaart, T.; Mootse, H.; Joudu, I. Fatty acid profile of milk from saanen and swedish landrace goats. Food Chem. 2018, 254, 326-332. [CrossRef]

39. Vinolo, M.A.; Rodrigues, H.G.; Nachbar, R.T.; Curi, R. Regulation of inflammation by short chain fatty acids. Nutrients 2011, 3 , 858-876. [CrossRef]

40. Kumari, M.; Kozyrskyj, A.L. Gut microbial metabolism defines host metabolism: An emerging perspective in obesity and allergic inflammation. Obes. Rev. 2017, 18, 18-31. [CrossRef] [PubMed]

41. Yao, Y.; Zhao, G.; Xiang, J.; Zou, X.; Jin, Q.; Wang, X. Lipid composition and structural characteristics of bovine, caprine and human milk fat globules. Int. Dairy J. 2016, 56, 64-73. [CrossRef]

42. Konuspayeva, G.; Lemarie, É.; Faye, B.; Loiseau, G.; Montet, D. Fatty acid and cholesterol composition of camel's (camelus bactrianus, camelus dromedariusand hybrids) milk in kazakhstan. Dairy Sci. Technol. 2008, 88, 327-340. [CrossRef]

43. Koletzko, B.; Rodriguez-Palmero, M. Polyunsaturated fatty acids in human milk and their role in early infant development. J. Mammary Gland. Biol. Neoplasia 1999, 4, 269-284. [CrossRef]

44. Bauer, J.; Heinemann, K.; Lees, G.; Waldron, M. Retinal functions of young dogs are improved and maternal plasma phospholipids are altered with diets containing long-chain n-3 polyunsaturated fatty acids during gestation, lactation, and after weaning. J. Nutr. 2006, 136, 1991S-1994S. [CrossRef]

45. Zicker, S.; Jewell, D.; Yamka, R.; Milgram, N. Evaluation of cognitive learning, memory, psychomotor, immunologic, and retinal functions in healthy puppies fed foods fortified with docosahexaenoic acid-rich fish oil from 8 to 52 weeks of age. J. Am. Vet. Med. A 2012, 241, 583-594. [CrossRef] [PubMed]

46. Khan, M.; Pasha, T.; Farooq, U.; Ditta, Y.; Ilyas, M.; Ahmad, H. Mapping of calcium and phosphorus status of buffaloes in different cropping zone of punjab province. J Anim. Plant Sci. Pak. 2012, 22, 315-318.

47. Haenlein, G.F.W. Past, present, and future perspectives of small ruminant dairy research. J. Dairy Sci. 2001, 84, 2097-2115. [CrossRef]

48. Anderson, R.S.; Carlos, G.M.; Robinson, I.P.; Booles, D.; Burger, I.H.; Whyte, A.L. Zinc, copper, iron and calcium concentrations in bitch milk. J. Nutr. 1991, 121, S81-S82. [CrossRef] 